\title{
Variability, Heritability and Genetic Advance Studies in Advanced Genotypes of Rice (Oryza sativa L.)
}

\author{
B. Manjunatha, Nagaraja Kusagur and B. Niranjanja Kumara
}

Agricultural and Horticultural Research Station, Kathalagere, University of Agricultural and Horticultural Sciences, Shivamogga, Karnataka, India

*Corresponding author

\section{A B S T R A C T}

\section{Keywords}

Heritability, Rice, Variability

\section{Article Info}

Accepted:

18 July 2020

Available Online:

10 August 2020
The experiment was composed of thirty five advanced rice genotypes with two replications in Randomized Complete Block Design conducted in Agricultural and Horticultural Research Station, kathalagere, University of Agricultural and Horticultural Sciences, Shivamogga in kharif 2018. The traits panicles per square metre and yield $\mathrm{kg} / \mathrm{ha}$ had higher GCV and PCV as well as high genetic variability and phenotypic variability. Yield $\mathrm{kg} / \mathrm{ha}$ had high heritability coupled with GCV and PCV.

\section{Introduction}

Rice (Oryza sativa L.) is regarded as one of the major cereal crops with high agronomic and nutritional importance. It is a major source of human food for more than half of the world's population (1). Rice is one of the food crops for which complete genome sequence is available. Therefore, it is an ideal model plant for study of grass genetics due to its relatively small genome size of $430 \mathrm{Mb}$ compared to other plants (2). Rice is a selfpollinated cereal crop belonging to the family Gramineae (synomym-Poaceae) under the order Cyperales and class Monocotyledon having chromosome number $2 n=24$ (1). The genus Oryza includes a total of 25 recognized species out of which 23 are wild species and two, Oryza sativa and Oryza glaberrima are cultivated (2).It can survive as a perennial crop and can produce a ratoon crop for up to 30 years but cultivated as annual crop and grown in tropical and temperate countries over a wide range of soil and climatic condition. Rice and agriculture are still fundamental to the economic development of most of the Asian countries. In much of Asia, rice plays a central role in politics, society and culture, directly or indirectly employs more people than any other sector. A healthy rice industry, especially in Asia's poorer countries, is crucial to the livelihoods of rice 
producers and consumers alike. Farmers need to achieve good yields without harming the environment so that they can make a good living while providing the rice-eating people with a high-quality, affordable staple. Underpinning this, a strong rice research sector can help to reduce costs, improve production and ensure environmental sustainability. Indeed, rice research has been a key to productivity and livelihood.

Rice is the second largest produce cereal in the world in 158.3million hectare area with annual production of about 685.24 millionmetric tons (3) and also the staple food for over one third of the world's population (4) and more than $90 \%$ to $95 \%$ of rice is produced and consumed is Asia (5). Rice (Oryza sativa L.) is the staple food in india and grown in a wide range of environments ranging from the upland areas like Chittagong Hill Tracts, Sylhet and Garo Hills, with little moisture, to situations where the water is 3-4 meter deep(6).

Yield enhancement is the major breeding objective in rice breeding programmes and knowledge on the nature and magnitude of the genetic variation governing the inheritance of quantitative characters like yield and its components is essential for effective genetic improvement. Acritical analysis of the genetic variability parameters, namely, Genotypic Coefficient of Variability (GCV), Phenotypic Coefficient of Variability (PCV), heritability and genetic advance for different traits of economic importance is a major pre-requisite for any plant breeder to work with crop improvement programs. The present investigation was under taken in this context to elucidate information on variability, heritability, genetic advance, character associations and path of effect in promising rice genotypes. A good knowledge of genetic resources might also help in identifying desirable genotypes for future hybridization program.

\section{Materials and Methods}

The experiment was carried out during kharif, 2018 at Agricultural and Horticultural Research station, kathalagere under University of Agricultural and Horticultural Sciences, Shivamogga, Karnataka. The material comprised of thirty five advanced rice genotypes own in a randomized complete block design with two replications with spacing of $20 \times 15 \mathrm{~cm}$. Data were recorded on five randomly selected plants in each entry in each replications for the traits days to $50 \%$ flowering, Plant height $(\mathrm{cm})$, Productive tillers $/ \mathrm{m}^{2}$ and Yield $\mathrm{kg} / \mathrm{ha}$. The data subjected to INDOSTAT software to estimate Genetic coefficient of variation (\%), phenotypic coefficient of variation (\%), Heritability (\%) (Broad sense), Genetic Advance and Genetic Advance as percent of mean. The estimates for variability treated as per the categorization proposed by Siva Subramanian and Madhavamenon (4), heritability and genetic advance as percent of mean estimates according to criteria proposed by Johnson et al., (2).

\section{Results and Discussion}

In the present study analysis of variance revealed the existence of significant differences among genotypes for all traits studied. The mean, variability estimates i.e., Genetic coefficient of variation (\%), phenotypic coefficient of variation (\%), Heritability (\%) (Broad sense), Genetic Advance as percent of mean are presented in table 1. All traits under studied have higher phenotypic coefficient of variation than genotypic coefficient of variation. The magnitude of phenotypic coefficient of variation and genotypic coefficient of variation was moderate to high for the traits panicles per square metre and yield $(3,5)$. The high PCV observed for yield per hectare (5). 
Table.1 Variability, heritability and genetic advance for quantitative traits in rice

\begin{tabular}{|c|c|c|c|c|c|c|}
\hline Character & Mean & $\begin{array}{c}\text { Genetic } \\
\text { coefficient of } \\
\text { variation (\%) }\end{array}$ & $\begin{array}{c}\text { Phenotypic } \\
\text { coefficient of } \\
\text { variation (\%) }\end{array}$ & $\begin{array}{c}\text { Heritability } \\
(\boldsymbol{\%})\end{array}$ & $\begin{array}{c}\text { Genetic } \\
\text { advance (\%) }\end{array}$ & $\begin{array}{c}\text { Genetic } \\
\text { advance as } \\
\text { percent mean }\end{array}$ \\
\hline $\begin{array}{c}\text { Days to fifty percent } \\
\text { flowering }\end{array}$ & 117 & 9.90 & 11.04 & 0.98 & 25.88 & 21.46 \\
\hline Plant height(cm) & 76 & 17.78 & 17.40 & 0.93 & 23.18 & 33.44 \\
\hline Panicles per m $\mathbf{~ m}^{\mathbf{2}}$ & 389 & 22.05 & 20.65 & 0.80 & 155.00 & 34.66 \\
\hline Yield kg/ha & 3558 & 30.6 & 30.36 & 0.95 & 2258.00 & 53.54 \\
\hline
\end{tabular}

The high GCV obtained for number of panicles per square metre indicating the improvement is possible through selection. Genotypic coefficient of variation measures the extent of genetic variability percent for a trait but does not assess the amount of genetic variation which is heritable. Heritability estimates were high for all the characters.

The heritability estimates along with genetic advance can be useful to predict effect of selection in selection programmes. The traits like days to fifty percent flowering, yield (7) and plant height exhibited high magnitude of genetic advance as percent of mean.

The traits plant height, days to fifty percent flowering, panicles per square metre and yield have high heritability along with genetic advance as percent of mean indicate that these characters attributable to additive gene effects which are fixable revealing that improvement in these characters would be possible through direct selection.

\section{References}

1. Genetic variability and association analysis in rice. International Journal of Applied
Biology and Pharmaceutical Technology. 5(2): 63-65.

2. Johnson, H.W. Robinson, H.F. and Costock, R.E., Estimates of genetic and environmental variability in Soyabean. Agronomy Journal, 47(7): 314-318 (1955)

3. Roy, B. Hossain, M. and Hossain, F., Genetic variability in yield components of rice (Oryza sativa L.). Environment and Ecology. 19(1): 186-189 (2001).

4. Siva Subramanian, S. and madhavamenon, P., Combining ability in rice. Madras Agricultural Journal. 60: 419-421 (1973)

5. ThirumalaRao, V. Chandra Mohan, Y. Bhadru, D. Bharathi, D. and Venkanna,. V. (2014).

6. Venkanna, V., Lingaiah, N., Raju, Ch and Rao, V.T., Genetic studies for quality traits of $\mathrm{F}_{1}$ population of rice (Oryzasativa L.). International Journal of Applied Biology and PharmaceuticalTechnology. 5(2): 125127 (2014)

7. Vaithiyalingan, M. and Nadarajan, N., Genetic variability, heritability and genetic advance in $\mathrm{F}$ population of inter subspecific crosses of rice. Crop Research. 31(3): 476-477 (2006).

\section{How to cite this article:}

Manjunatha, B., Nagaraja Kusagur and Niranjanja Kumara, B. 2020. Variability, Heritability and Genetic Advance Studies in Advanced Genotypes of Rice (Oryza sativa L.). Int.J.Curr.Microbiol.App.Sci. 9(08): 1668-1670. doi: https://doi.org/10.20546/ijcmas.2020.908.191 